\title{
Correction to: Measuring school children's attitudes toward immigrants in Switzerland and Poland
}

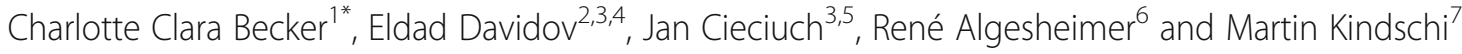

Correction to: Measurement Instruments for the

Social Sciences 2, 9 (2020)

https://doi.org/10.1186/s42409-020-00017-0

The original article (Becker, Davidov, Cieciuch, Algesheimer, \& Kindschi, 2020) mistakenly omits an acknowledgement which the authors would like to state ahead in this correction article:

\section{Acknowledgements \\ The authors would also like to thank Oliver Bieber for the illustrations of the immigrant children. \\ Author details \\ ${ }^{1}$ Cologne Graduate School in Management, Economics and Social Sciences and Institute of Sociology and Social Psychology, University of Cologne, Albertus-Magnus-Platz, 50923 Cologne, Germany. ${ }^{2}$ Institute of Sociology and Social Psychology, University of Cologne, Cologne, Germany. ${ }^{3}$ URPP Social Networks, University of Zurich, Zurich, Switzerland. ${ }^{4}$ Department of Sociology, University of Zurich, Zurich, Switzerland. Institute of Psychology, Cardinal Stefan Wyszyński University in Warsaw, Warsaw, Poland. ${ }^{6}$ Department of Business Administration, URPP Social Networks, University of Zurich, Zurich, Switzerland. ${ }^{7}$ Jacobs Center for Productive Youth Development, University of Zurich, Zurich, Switzerland.}

Published online: 14 April 2021

\section{Reference}

Becker, C. C., Davidov, E., Cieciuch, J., Algesheimer, R., \& Kindschi, M. (2020). Measuring school children's attitudes toward immigrants in Switzerland and Poland. Measurement Instruments for the Social Science, 2, 9. https://doi.org/1 0.1186/s42409-020-00017-0

The original article can be found online at https://doi.org/10.1186/s42409020-00017-0

* Correspondence: becker@wiso.uni-koeln.de

${ }^{1}$ Cologne Graduate School in Management, Economics and Social Sciences and Institute of Sociology and Social Psychology, University of Cologne,

Albertus-Magnus-Platz, 50923 Cologne, Germany

Full list of author information is available at the end of the article

(c) The Author(s). 2021 Open Access This article is licensed under a Creative Commons Attribution 4.0 International License, which permits use, sharing, adaptation, distribution and reproduction in any medium or format, as long as you give appropriate credit to the original author(s) and the source, provide a link to the Creative Commons licence, and indicate if changes were made. The images or other third party material in this article are included in the article's Creative Commons licence, unless indicated otherwise in a credit line to the material. If material is not included in the article's Creative Commons licence and your intended use is not permitted by statutory regulation or exceeds the permitted use, you will need to obtain permission directly from the copyright holder. To view a copy of this licence, visit http://creativecommons.org/licenses/by/4.0/. 